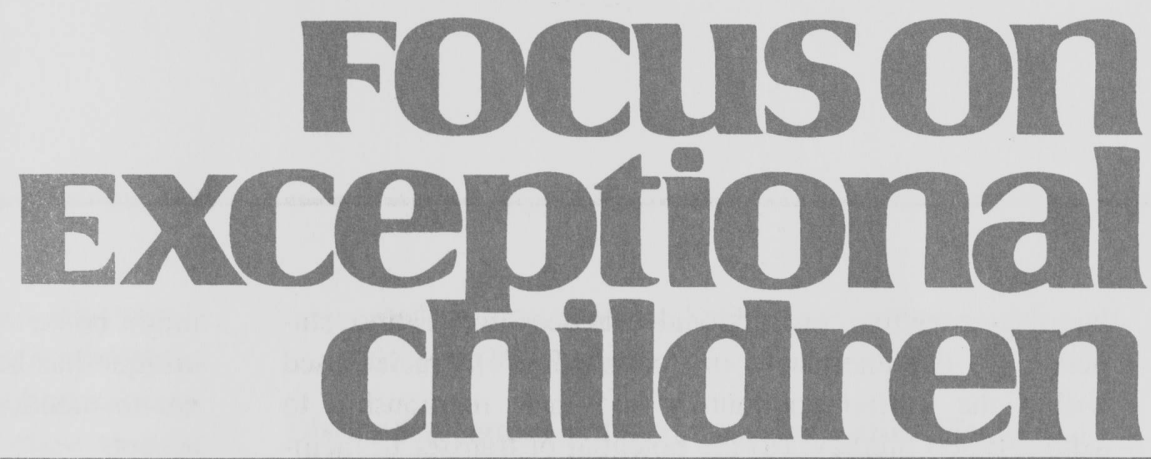

\title{
Fostering the Literacy Development of Latino Students
}

\author{
Robert T. Jiménez
}

The literacy achievement gap between White and Latino students has remained relatively static, as has progress in literacy for Latino students (NCES, 1998a). Valencia (1991) has written about what he calls the persistent, pervasive, and disproportionate academic failure of Chicano students. Valencia's assessment could reasonably be extended to other groups of Latino students, particularly those of Puerto Rican descent and also, possibly, students from Central American backgrounds.

Latino students have attracted the attention of educators, legislators, and the public in general because Latinos now constitute the largest group of minority students in U.S. schools, calculated at 13.5 percent of the total (NCES, 1998b). Latinos experienced a 59 percent growth rate during the 1990s (Pace, 2001).

Invariably, many students who are English language learners and who also are having difficulties with literacy will have contact with professionals in special education (Allington, 1989; Gersten, Brengelman, \& Jiménez, 1994). This is partly because of the high rate of growth of limited English proficient (LEP) students in regions and cities that have not previously served this population.

Of concern is that the professional development necessary to effectively address the needs of students from culturally and linguistically diverse backgrounds is not widely available. Because special education teachers often are called upon when students fail to "learn on schedule" or at what is considered an appropriate pace considering their age, they need information and support if they are to serve as student advocates. Cummins (1986) argues persuasively that students from language minority backgrounds are either empowered or disabled to the extent that "professionals involved in assessment become advocates for minority students rather than legitimizing the location of the problem in the student" (p. 21). Advocacy, of course, requires more than simply good intentions. Professionals who are effective in working with second language learning students are familiar with the unique learning needs of this population.

\section{EDUCATIONAL ISSUES}

The issues dealt with in this article examine the following roles played by teachers and educators, students, students' communities, and the larger societal context: (a) the professional development of educators, both preservice and inservice; (b) the optimal mix of

Robert Jiménez is an associate professor, University of Illinois at Urbana Champaign. 
language-sensitive instructional practices for Latino students; (c) the alternative or "contrasting" literacies used within the Latino community and their relationship to school-based literacy; (d) the potential of transfer to facilitate Latino students' literacy learning; (e) the prevailing sociopolitical environment with respect to Latino students and education; and (f) the questions raised by minority researchers and writers concerning the academic performance of Latino students.

\section{The Need for Informed Educators}

How can we provide preservice and inservice teachers with the necessary professional development to provide optimal literacy instruction to Latino students? As my colleague, Rosalinda Barrera, and I stated in a recent paper (Jiménez \& Barrera, 2000), teacher and administrator education programs seldom place the teaching of linguistically and culturally diverse students at the center of their programs. Instead, diversity is positioned as problematic and marginal to the main task of education. Schooling, in contrast, is considered beneficial for all students, everywhere, all the time (Nieto, 1992). The notion that diversity itself

\section{FOCuson Exceptional children}

ISSN 0015-511X FOCUS ON EXCEPTIONAL CHILDREN (USPS 203-360) is published monthly except June, July, and August as a service to teachers, special educators, curriculum specialists, administrators, and those concerned with the special education of exceptional children. This publication is annotated and indexed by the ERIC Clearinghouse on Handicapped and Gifted children for publication in the monthly Current Index to Journals in Education (CIJE) and the quarterly index, Exceptional Children Education Resources (ECER). The full text of Focus on Exceptional Children is also available in the electronic versions of the Education Index. It is also available in microfilm from Xerox University Microfilms, Ann Arbor, MI. Subscription rates: Individual, \$36 per year; institutions, $\$ 48$ per year. Copyright (C) 2002, Love Publishing Company. All rights reserved. Reproduction in whole or part without written permission is prohibited. Printed in the United States of America. Periodical postage is paid at Denver, Colorado. POSTMASTER: Send address changes to:

$$
\begin{gathered}
\text { Love Publishing Company } \\
\text { Executive and Editorial Office } \\
\text { P.O. Box } 22353 \\
\text { Denver, Colorado } 80222 \\
\text { Telephone (303) 221-7333 }
\end{gathered}
$$

Karen Harris

University of Maryland
Thomas Skrtic University of Kansas
James Shriner University of Illinois
Erica J. Lawrence Editor
Stanley F. Love

Publisher might be beneficial and that schooling might be in need of critique has been a difficult concept for many educatorsnot to mention the general public and policy makers-to accept.

In addition, teachers at all levels learn and teach a view of literacy that is mainstream and antagonistic to the needs and abilities of a diverse populace (Moll, 1988; NCES, 1997). At the very least, the linguistic and cultural knowledge that Latino students bring into U.S. classrooms is unknown to many educators, unexplored by mainstream researchers, and unacknowledged in prevailing instructional methods and curriculum materials. Inclusive instruction "must begin with the explicit premise that each learner brings a valid language and culture to the instructional context" (Reyes, 1992, p. 427).

What my colleagues and I have argued is that an additional shift in perspective is needed-one that treats diversity as the norm and also sees the possibilities created by diversity. We believe that these possibilities have the potential to benefit all students, including those from mainstream, monolingual, middle-class backgrounds. For example, mainstream students need to learn appropriate ways to interact in diverse settings, and they also can benefit from exposure to non-English languages. At the least, this shift in perspective would have us recognize these students and their families as sources of knowledge and as consumers and producers of multiple literacies (Guerra, 1998; Luke, 1995-1996).

The advantage of a multiple versus a single literacy approach is that it provides teachers and students with access to a broader set of activities, materials, and purposes for literacy than that encompassed within what is typically thought of as "school-based literacy." Attempts to teach this latter type of literacy have not been particularly effective with members of many culturally and linguistically diverse groups within the United States (Macedo, 1994).

The New London Group (1996) outlined some of the critical features that a multiple literacies approach would entail:

\footnotetext{
To be relevant, learning processes need to recruit, rather than attempt to ignore and erase, the different subjectivities-interests, intentions, commitments, and purposesstudents bring to learning. Curriculum now needs to mesh with different subjectivities, and with their attendant languages, discourses, and registers, and use these as a resource for learning. (p. 72)
}

In a sense, members of The New London Group are reminding educators to think more deeply about instructional design and choice of materials. The goal is to acknowledge and respect students as capable and potentially successful, to recognize the linguistic and cultural knowledge that learners bring into the classroom. Perhaps what is 
new about their recommendation is that, while they advocate recognition, understanding, and respect for both the language and culture of diverse groups - a perennial concern of multicultural educators - they also promote specific and visible inclusion of this information in the school curriculum for all students.

In addition, their stance recognizes the curriculum of the school and mainstream ways of thinking, learning, reading, and writing as powerful discourses to which all students need access but which also require critical analysis. The following items are offered as a first step toward fleshing out the vision just proposed and discussed.

- Educators and schools that are effective with Latino students are familiar with programs in which Latino students achieve success. They also are familiar with program evaluation research on effective schools for language minority students. Researchers such as Eugene García (1994), William Tikunoff (1985), Thomas Carter (1986), Tamara Lucas, Rosemary Henze, and Ruben Donato (1990) have described some of these programs in their articles and books. All of the programs they describe actively recognize and promote students' first-language strengths, accept and celebrate their cultures, and implement visible efforts to combat racism and social injustice.

- Teachers and administrators who are effective with Latino students obtain relevant professional development. This development typically involves completion of coursework, as well as relevant professional experience in second language acquisition, English as a second language, multicultural education, and bilingual education.

- Educators who are effective with Latino students recognize the long-term nature of second language acquisition, particularly literacy development. Monolingual individuals typically underestimate the amount of time necessary to become fluent in a second language, particularly with respect to literacy. Research (Collier, 1987; Thomas \& Collier, 1996) suggests that students may attain full grade level proficiency within as few as 2 years but also might require as many as 8 years, depending on factors such as age on arrival to the United States and previous academic achievement in their country of origin. Overall, however, the attainment of age-appropriate, grade level achievement in a second language is typically a 4- to 5-year process.

- Students' cultural and linguistic backgrounds are viewed as sources of strength, not deficits to be overcome. Students' backgrounds are not viewed as barriers but, rather, as foundations for future learning. In practical terms, students are described as speakers, readers, or writers of Spanish rather than simply as non-English speakers.

\section{Distinctive Nature of Instruction for Latino Students}

What is the optimal amount of language-sensitive literacy instruction to foster and successfully establish literacy for Latino students? What combination of sheltered English, English as a second language, and native language literacy instruction is necessary to accomplish this goal?

This question gets to the heart of what is most troublesome to many mainstream educators: Why don't Latino students and many other English language learners follow the same patterns of learning as mainstream students? Collier (1987) projected that a time span of anywhere between 2 to 8 years is necessary for immigrant students from a variety of national and language backgrounds arriving in the United States between the ages of 5 to 15 years old to attain gradelevel norms in academic achievement. This projection was made for students from middle class and upwardly mobile families who were recent immigrants with successful students in the countries of origin.

The students in Collier's research received all of their instruction in English with language arts instruction, algebra, biology, and some other classes on an as-necessary basis provided by ESL teachers. Note that the 2 to 8 years probably covers the vast majority of students who must, in addition to learning all that is required at each grade level, also learn a new language. Note also that there is a great deal of variation in terms of time necessary to reach this level of achievement.

Perhaps the most interesting finding from Collier's research is that the amount of time necessary depends on factors such as age on arrival to the United States, which functions as a proxy for the number of years of prior schooling. Students who begin schooling in the United States after age 8 often have completed at least 2 to 3 years of schooling in their home country. This cognitive and academic background can be helpful to students as they learn a new language.

We know from later research (Thomas \& Collier, 1996) that English language learning immigrant students make continuous progress in learning English and in academic achievement for as long as they receive well designed, linguistically sensitive instruction. That is, students in dual language immersion programs demonstrated the highest ultimate levels of academic achievement by grade 12 as compared to students in transitional bilingual education programs, both early and late exit varieties, and in comparison to structured English-immersion programs.

Submersion models, or all-English instruction in the general education classroom, both with and without an ESL component, fared the worst, with student means falling 
between the 20th and 40th percentile of National Center for Education Statistics. The provision of services and the quality of those services, then, seem to be two of the most critical features of instruction for English language learners, particularly immigrant students. One of the advantages of dual language immersion and late exit bilingual instruction is that the former is designed to continue providing services through grade 12 , whereas the latter is intended to provide services through grade 6 . These programs differ considerably from early exit bilingual instruction and sheltered English instruction because services in these models typically are terminated by or before grade 3 . Only program models that include substantial native language instruction go beyond 2 or 3 years of support for English language learners.

The intermediate grades (4 and 5) and middle school years $(6,7$, and 8$)$ are especially important because student performance during this period influences high school completion rates. Grade 4 is a critical juncture for all students, mainstream and Latino, because of the increase in curriculum demands at that level. These are also the years when Latino students who are learning English have been found to lose ground on language and literacy assessments. Further, this is the time when many language minority students have completed their transition from bilingual and ESL programs to the general education classroom, where all instruction is provided in English. Too many Latino students lag at this point and may be referred for special education services.

In consequence, many of these students begin to view schooling as a painful and humiliating ordeal, possibly unnecessary. Unique in comparison to their mainstream counterparts, Latino students may encounter a curriculum that requires high levels of English literacy for the first time as they move into the intermediate and middle school levels. This last fact alone is a strong argument for carefully considering the design of their instructional programs and the services offered to them.

Special language support for English language learners is least likely to be found at the middle school and high school levels. Latino students who first enter the United States during these years face a challenging and densely packed curriculum, as well as the possibility of not receiving either ESL or native language instruction. Of even further concern is that many Latino students are from working class or rural backgrounds, which often means that their access to schooling prior to arriving in the United States may have been limited or even unavailable. In addition, the schools they attend in the United States are often poorly funded and are located in urban settings. All of these factors can have a negative cumulative impact on the academic changes facing Latino students and have to be taken into account when considering group achievement.

\section{Alternative Literacies}

Which literacies are most readily recognizable to Latino students? Which literacies have the most potential to help Latino students accomplish their goals? What is the relationship between these literacies and literate practices commonly found in schools?

The possibilities and the promise of alternative literacies for reconceptualizing schooling for Latino students is probably one of the most exciting developments in education today. My research (Jiménez, 2000) found that preadolescent and young adolescent Latino students view particular forms of literacy, or non-school literacies, as highly necessary and desirable. Their parents often depend on them for help to negotiate the demands of English language literacy. The students serve as language brokers to their parents, translating documents such as rental/lease agreements, income tax forms, and other commercial transactions such as telephone and power bills. Many Latino students take these responsibilities seriously and view the help they provide to their parents and other family members as their contribution to the overall well being of the family.

In addition, parents and other adult family members sometimes depend on their children for oral translation in stressful, high-paced interactions such as purchasing a vehicle or returning merchandise to a retail establishment. All of these activities may be viewed as alternative forms of literacy with respect to school-based literacy.

\section{Research on Multiple Literacies}

Gregory and Williams (2000) have expanded the notion of multiple literacies by highlighting the distinctive natures of specific literate practices among members of culturally and linguistically diverse communities living in London. Through careful examination of succeeding waves of immigrants living in the Spitalfields borough, they proposed the notion of "contrasting literacies."

One of the communities they examined, Bengali-Sylheti speakers, brought Q'uranic and Bangladeshi literate practices with them into the British school system. Analysis revealed that at first these contrasting literacies created points of tension for students and teachers. With time, though, the students and their families and communities created "syncretic literacies." These latter practices fused elements of school-based English literacy with those the students brought into the schools. The researchers concluded their study by referring to students' out-of-school literacies as "treasure troves" of experiences and information with attending benefits for students and teachers alike.

Of particular interest is that certain instructional practices employed by the British teachers fostered and supported their students' learning whereas others discouraged it. For 
example, students found that choral reading was compatible with their previous learning. On the other hand, the students found some instructional techniques difficult to reconcile with their out-of-school experiences. For example, teachers repeated students' oral reading as a backdrop for asking questions and to stimulate reflection on the text. The Bengali-British children, accustomed to "echo reading", instinctively repeated what the teacher said to them, just as they did in the Q'uranic and Bengali reading classes. For the most part, however, teachers seemed to be unfamiliar with students' out-of-school literacies and did not consciously connect their instruction to practices that were familiar to the students.

\section{Out-of-School Literacies}

For Latino students living in the United States, a growing body of research is beginning to identify language practices and literate behaviors that parallel those of the BengaliBritish children examined by Gregory and Williams. I propose that these practices, as they become better documented and understood by researchers, could serve as a bridge for improved and more effective literacy instruction within schools (Barrera \& Jiménez, 2000, 2001; Moll, 1988; Reyes, 1992).

Students also may observe or participate in other forms of literacy such as letter-writing activities that involve distant relations in foreign countries. Guerra (1998) described the distinctiveness of this form of literacy as it is used by Mexican immigrants, and he demonstrated in his analysis how it differs from mainstream forms employed in schools. For example, the Mexican immigrants use specific formulaic phrases and their purposes for writing are highly concrete. Kalmar (2001) documented an intriguing case of adult Latino immigrants who created their own writing system for the purpose of transcribing oral English.

An important question for teachers and researchers has to do with how we can build upon these out-of-school literacies so that Latino students receive the benefits associated with their practice. We know that mainstream, middle class forms of literacy such as storybook reading and certain types of written expression dovetail nicely with reading and writing instruction in the beginning grades (Heath, 1983; Sulzby \& Teale, 1991, Wells, 1986). I propose that the literacies that many Latino students bring into the schools are at least as complex and demanding as those possessed by their middle class, European American counterparts. Why can't curriculum and instruction be designed to build on and acknowledge these non-school literacies that are familiar and perhaps even more practical to Latino students?

In the following example, Gil discusses the intricacies of "language brokering." Compare this activity, so familiar to
Gil and many other Latino students, with your own understanding of the ways in which mainstream students make use of literacy.

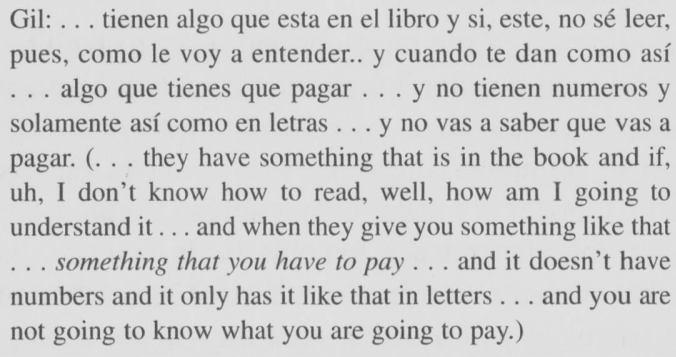

Gil: ... tienen algo que esta en el libro y si, este, no sé leer, pues, como le voy a entender.. y cuando te dan como así ... algo que tienes que pagar ... y no tienen numeros y solamente así como en letras ... y no vas a saber que vas a pagar. (. . . they have something that is in the book and if, uh, I don't know how to read, well, how am I going to understand it ... and when they give you something like that ... something that you have to pay ... . and it doesn't have numbers and it only has it like that in letters ... and you are not going to know what you are going to pay.)

Notice that Gil understands and appreciates the power of literacy, not only for its own sake but also because of the real world consequences of paying or not paying bills. These consequences might mean the difference between having or not having a place to live or phone service. In the following examples and suggestions for instructional practice, I have considered what students such as Gil taught me about the alternative literacies with which they are familiar, and I have attempted to make recommendations accordingly.

- Language brokering, both oral and literate, should be formally recognized as a legitimate and commendable activity. Students can be provided with instruction that helps them to complete these tasks successfully. Teachers may want to investigate how many of their students are involved in these activities, their feelings about the activities, and what they think would help them to accomplish these tasks more effectively. Instructional activities could be designed accordingly.

- Bilingual oral and literate abilities ought to be promoted and encouraged because students need these skills to manage their lives effectively. Business people from the local area could be invited into the school to discuss the ways in which they use both English and Spanish in their work. Alternatively, students could visit local businesses and note how written Spanish and English are used in restaurants, travel agencies, beauty salons, and grocery stores.

- Other literate activities that are uniquely of interest to Latino students and can be encouraged and included in the curriculum include ideas that students can use to facilitate younger siblings and older family members' literacy, letter writing to relatives who live abroad or in another state, and other activities as yet unknown in general but perhaps recognized at the local school level. Just as many schools recognize and reward outof-school story book reading, the same practice could be extended to reading with younger siblings, participating in letter writing to family members abroad or in another state. Teachers might also want to investigate 
whether students are aware of other ways that literacy is employed in their homes and communities.

\section{The Potential of Transfer}

The question of the most optimal ways to facilitate students' ability to transfer information from first language and life experience to school-based tasks deals with a classic concern in bilingual education. For example, the issue of linguistic transfer is a major component in Cummins' (1979) linguistic interdependence hypothesis. In essence, he proposes that students who receive effective instruction in their native language will transfer what they know if they have adequate exposure to the second language and adequate levels of motivation to learn the second language.

In previous research, my colleagues and I documented that successful bilingual readers consciously transferred information across their two languages (Jiménez, García, \& Pearson, 1995). If they were reading a text in English that dealt with the solar system, they would consciously and specifically recall having read Spanish-language text covering the same or a similar topic. In contrast, low- and average-performing bilingual students have much more difficulty knowing when and how to make connections between their two languages; in fact, they appear to view their two languages as mutually disparate and even antagonistic systems (Jiménez, García, \& Pearson, 1996).

These stances towards biliteracy may have been instructionally induced by an educational system that does not understand, value, or incorporate the advantages of bilingualism into the curriculum. Prevailing deficit views of Latino students, which consider them to be defective versions of their mainstream counterparts, fail to recognize their linguistic resources and how these might be used to facilitate learning.

Taking the findings of my earlier research, which documented and catalogued the cognitive and metacognitive strategies of competent and less competent bilingual Latino students, I taught some of this information to much lowerperforming Latino students, students in bilingual special educational settings, and what their school called a bilingual at-risk classroom. A finding from that research was that these middle school students, who were all performing at least three grade levels behind their expected level, responded quite favorably to instruction that emphasized a bilingual approach to processing text (Jiménez, 1997). They were more than willing to try out a searching-for-cognatevocabulary strategy, a translating strategy, and strategies designed to facilitate the integration of their prior knowledge and experience with information found in text.

The following example shows how a successful bilingual Latina reader actively used her knowledge of Spanish to improve her comprehension when reading in English:
Pamela: Like "carnivorous," "carnívoro." OK, some [words] like I know what it is in Spanish. Some words I go, what does that mean in Spanish?

I argued that these strategies were desirable to these students because they were derived from their community, from other bilingual Latino students. I speculated that they were able to intuitively understand and appreciate the benefits that accrued from establishing linkages between their two languages. I also concluded that this approach affirmed their bilingual, bicultural identity. It is possible that prevailing stereotypes about Latino students, their families, and their communities prevent many educators from seeing the full academic potential of Latino students. One especially pernicious stereotype is that knowledge of any non-English language is harmful and potentially confusing for minority students.

In the following recommendations, I encourage teachers to explicitly acknowledge all of the knowledge and experience their English language learning Latino students bring with them into the classroom. The use of transfer strategies is an attempt to support and scaffold students' learning and help them make maximum use of what they already know.

- Educators who wish to be inclusive and supportive of their Latino students make special efforts to understand and consider the unique challenges and special talents the bilingual students possess. For example, educators know that successful bilingual readers use the following strategies:

- Approaching unknown vocabulary, which involves use of contextual clues, looking for cognate relationships, and the approximate pronunciations of words.

- Asking questions, which involves overt comprehension monitoring.

- Making inferences, which includes the integration of prior knowledge, including bilingual language abilities, with information found in print.

When less successful bilingual students are taught these strategies, they can use them in ways similar to more successful bilingual readers.

- These same educators obtain and examine their students' prior educational histories for information to guide instructional efforts. Students from rural backgrounds in their country of origin, for example, may need more intensive literacy instruction than students coming from urban experiences in their home countries.

- Students who are recent immigrants and who have had minimal prior schooling are provided with an appropriate beginning literacy program. This program mixes and matches characteristics of programs used 
with young children and programs used in adult literacy programs. The guiding principle is to challenge the student with as many age-appropriate materials as possible while making sure that success is possible.

- Many older Latino students need help with word identification skills and reading fluency even at the intermediate and middle school levels. Although their needs may be similar to those of younger students, age-appropriate materials are necessary. I have found that struggling Latino readers at the middle school level respond well to literacy instruction that is grounded in culturally familiar texts, is linguistically sensitive, and emphasizes choral and repeated reading.

- Students are encouraged to view their dual language abilities as a strength. One way to do this is to show them how to make connections across and between their two languages by accessing cognate vocabulary, by judicious use of translation, and by transferring information learned via their first language.

- Students are told explicitly how to overcome comprehension problems associated with second language learning. Typical comprehension problems for second language readers include encountering a disproportionately high number of unknown vocabulary words, use of idiomatic expressions, and lack of necessary background knowledge. Teachers can model the think-aloud procedure for students. This can be accomplished by reading a text silently, line by line, and then talking aloud and describing how comprehension problems are handled. For example: "Isn't it interesting that in this story by Sandra Cisneros, the father is going to Mexico. I remember when that happened in my family. My grandfather, who lived in Mexico, died, and my dad had to get on a plane and go to the funeral." Examples like this help students to see how an expert reader connects information in the text to her or his own life.

- Students are explicitly helped with reading strategies that have been shown to promote the comprehension of readers in general. These strategies include rereading, monitoring of comprehension, using background knowledge appropriately, drawing inferences, and asking questions and finding answers. An example showing how this researcher taught middle school students to ask questions is:

Sara: Quetzalcoatl wanted very much to help the people that he loved.

Researcher: Okay, what's your question now? What kind of question would you ask yourself? He wants very much to help the people that he loves so you wonder, well

Sara: Is it gonna happen or not?

The same middle school student commented that although she had until then disliked reading, by the end of 10 lessons emphasizing the approach described in this article, she now "kind of liked it because it makes a little more sense now and I can read better."

\section{Xenophobia and Linguicism}

Why are mainstream educators, researchers, policy makers, and the general public so eager to believe negative and damaging reports concerning bilingual/multicultural education? Xenophobia is, of course, an unreasonable fear of foreigners, but the term "linguicism" is not always as readily recognized. My definition would be an unreasonable fear or disdain of languages or dialects other than that of mainstream, standard U.S. English. One can often see and hear this disdain in public places where speakers of non-English languages are present.

In California and Arizona, antibilingual education forces have built upon xenophobic and linguicist attitudes and have portrayed bilingual education as something harmful to Latino students. The Ocean Side school district, for example, has reported miniscule gains on the SAT-9 test as "proof" that native language instruction is ineffective (Steinberg, 2000). Note that the scores being reported fall well within the range described by Thomas and Collier (1996) as typical for submersion programs with ESL components.

What the school district didn't report was that many other districts in the state of California posted similar or even greater gains. These were districts that continued to provide native language instruction and those that had never had native language instruction, as well as those that eliminated native language instruction (Butler, Orr, Bousquet, \& Hakuta, 2000). In other words, one has to look elsewhere for the 9 percentage point average increase, now at the 28th percentile, posted by this district. Yet, the mainstream media reported this change as if no further discussion were needed on this topic.

In his 1940 book, Forgotten People, George I. Sánchez wrote passionately and convincingly of the need for special teacher training, for inclusion of culturally relevant and linguistically comprehensible instruction. Some of the issues he addressed-and for which the community fought long and hard to achieve-are currently in danger of elimination. In our time, Guadalupe San Miguel (1987), and more recently Ruben Donato (1997) and Lourdes Diaz Soto (1997), have documented the protracted and bitter battle waged by the Latino community for bilingual education. 
The amount of research support for the benefits of native language instruction is substantial and has proved convincing when subjected to impartial and scholarly examination (General Accounting Office, 1987; Thomas \& Collier, 1997; Willig, 1985). As Macedo (2000) so cogently stated,

\begin{abstract}
The present assault on bilingual education is fundamentally political. The denial of the political nature of the debate is in itself, a political action. In examining the poor performance of linguistic minority students it is both academically dishonest and misleading to point to the failures of bilingual education without examining the larger context of the general failure of public education in major urban areas, which has created minority student dropout rates ranging from $50 \%$ to $65 \%$ in the Boston public schools to over $70 \%$ in larger metropolitan areas such as New York City. (p. 15)
\end{abstract}

\section{Promising Instructional Models}

Why haven't successful forms of bilingual education received as much attention as more problematic examples? Finding problematic results with bilingual education isn't difficult because, as Macedo pointed out, so many programs are located in impoverished urban school settings. These districts seldom receive necessary levels of funding and they often have many other problems in addition to those found within schools. Carter and Chatfield (1986) pointed out some time ago that finding effective bilingual programs can be difficult because so few are housed within effective schools. Programs are much more likely to be influenced by their placement in an effective school than vice versa. Putting the two components together ought to be the goal of everyone concerned with the academic progress of Latino students.

Positive results, however, have been reported in evaluations of dual language immersion programs (Christian, Howard, \& Loeb, 2000; Lindholm-Leary, 2001). Actually, the literacy needs of Latino students might be met best in these programs. Dual language immersion is proving to be the most inclusive in terms of students, languages, and literacies. These programs have tremendous potential for increasing the academic achievement and second language acquisition of mainstream and language minority students alike (Fishman, 1982; Thomas \& Collier, 1996).

In these programs, students receive at least half of their instruction in Spanish and the other half in English. These programs have many variations. Some offer mornings in English and afternoons in Spanish. Others alternate days in one language and then the other. Some even alternate semesters. Administrators work to ensure that approximately half of the students enrolled in these programs are native English speakers and the other half native speakers of a non-English language - in this case, Spanish.

Dual language programs that continue into the middle and high school years avoid the problems of many transitional bilingual education programs-i.e., the tragic loss of communicative and literate abilities in the student's native language - and foster more complex literacies including biliteracy (Jiménez \& Barrera, 2000).

In sum:

- Depending on the availability of staff, resources, and community input, school districts need to work toward upgrading their programs designed for Latino and other English language learning students. A hierarchy of programs, displaying which programs have been most effective for which types of students, can be found in the work of Thomas and Collier (1996).

- Ongoing professional development opportunities are needed for all staff members who work with Latino students. High quality professionally derived information concerning the academic achievement of Latino students has to be made available to teachers and other professionals working with these students. These opportunities can be created through cooperative agreements with local universities.

- Opportunities to observe effective sheltered English teachers, content-based ESL teachers, bilingual teachers, and general education teachers can make good practice models available to novice teachers and others who wish to improve their practice.

\section{A LATINO PERSPECTIVE}

Why haven't we as educators been more willing to carefully consider answers to the questions posed by researchers and theorists such as Donaldo Macedo? At present, the discussion is dominated by politically conservative voices, many of which are grounded in questionable views concerning immigrants (Crawford, 2000). In his most recent article, Macedo (2000, p. 19), asks the following questions:

Does cultural subordination affect academic achievement?

What is the correlation of social segregation and school success?

What role does cultural identity among subordinated students play in linguistic resistance?

Does the devaluation of students' culture and language affect reading achievement?

Is class a factor in bilingual education? Do material conditions that foster human misery adversely affect academic development?

These questions go to the heart of the matter concerning the language and literacy development of Latino students. They move away from deficit views of Latino students and hold our public institutions accountable for bringing about real reform and improvement in how we educate Latino 
students. They move us away from simplistic and reductionistic approaches to literacy instruction such as the current obsessive concern with teaching English while simultaneously devaluing and eliminating students' Spanish language knowledge. They also move us away from a monomaniacal obsession with teaching sound-symbol correspondences to more substantive matters.

These reductionistic approaches primarily entail means for manipulating young Latino students and do not address how we can then interact honestly and with integrity with them as they enter middle and secondary school. It is at this time when they realize that schooling has been designed primarily to strip them of their linguistic and cultural heritage. At this point, short-sighted approaches to working with Latino students pay devastating dividends. Sadly, many students are so alienated from schooling that they look for alternatives such as dropping out.

At the very least, when politically conservative views are presented, there ought to be the chance to hear or read an alternative perspective. These perspectives and researchbased views often are available through the websites of the National Association for Bilingual Education, and state and federal sources.

In conclusion, while my colleague Rosalinda Barrera and I (Jiménez \& Barrera, 2000) are literacy researchers and teacher educators who believe strongly in the transformative potential of literacy, we are well aware that political literacy - the kind that gets Latino parents to vote-is what matters most. Within a few years Latinos will constitute the largest minority group in the United States, and by the end of the century, some estimates are that Latinos will make up one third of the entire country's population (NCES, 1998a,c).

Numbers translate into votes and votes into political clout-but not without political literacy, which in turn leads to economic development and more adequate healthcare. These in turn influence literacy development every bit as much or more than traditional concerns that are confined to school literacy. We would like to advocate for such a criti$\mathrm{cal} /$ radical curriculum in contrast to the extremely limited choices offered by politicians and some literacy policy makers (Freire \& Macedo, 1987).

\footnotetext{
Note: This work was supported in part by a grant from the Division of Innovation and Development, Office of Special Education Programs, \#HO23N70037-97. The opinions included in this report are those of the author and do not necessarily reflect the position or endorsement of the Division of Innovation and Development, Office of Special Education Programs.
}

\section{REFERENCES}

Allington, R. L. (1989). School response to reading failure: Instruction for Chapter 1 and special education students in grades two, four, and eight. Elementary School Journal, 89(5), 529-542.

Barrera, R. B., \& Jiménez, (2000). What bilingual education teachers have to say about their literacy practices for Latino students. Washington, DC: National Clearinghouse for Bilingual Education. http://www. ncbe.gwu.edu/ncbepubs/reports/literacy/index.htm

Barrera, R. B., \& Jiménez, R. T. (2001). Bilingual teachers speak about the literacy instruction of bilingual Latino students. In B. M. Taylor \& P. D. Pearson (Eds.), Teaching reading: Effective schools and accomplished teachers (pp. 335-360). Mahwah, NJ: Lawrence Erlbaum.

Butler, Y. G., Orr, J. E., Bousquet, M., \& Hakuta, K. (2000). What can we learn about the impact of Proposition 227 from SAT-9 scores? NABE News and Notes, 24(1), 8-10.

Carter, T. P., \& Chatfield, M. L. (1986). Effective bilingual schools: Implications for policy and practice. American Journal of Education, 95(1), 200-232.

Christian, D., Howard, E. R., \& Loeb, M. I. (2000). Bilingualism for all: Two-way immersion education in the United States. Theory into practice, 39(4), 258-256.

Collier, V. P. (1987). Age and aquisition of second language for academic purposes. Tesol Quarterly, 21(4), 617-641.

Crawford, J. (2000). At war with diversity. Buffalo, NY: Multilingual Matters.

Cummins, J. (1979). Linguistic interdependence and the educational development of bilingual children. Review of Educational Research, 49(2), 222-251.

Cummins, J. (1986). Empowering minority students: A framework for intervention. Harvard Educational Review, 56(1), 18-36.

Donato, R. (1997). The other struggle for equal schools: Mexican Americans during the civil rights era. Albany: State University of New York.

Fishman, J. A. (1982). Sociolinguistic foundations of bilingual education. Binghamton, NY: Bilingual Press/Editorial Bilingüe.

Freire, P., \& Macedo, D. (1987). Literacy: Reading the word and the world. South Hadley, MA: Bergin \& Garvey.

García, E. (1994). Understanding and meeting the challenge of student cultural diversity. Boston: Houghton Mifflin.

General Accounting Office (1987, March). Bilingual education: A new look at the evidence. Washington, DC: GAO. (Rep. GAO/PEMD-87-12BR)

Gersten, R., Brengelman, S., \& Jiménez, R. (1994). Effective instruction for culturally and linguistically diverse students: A reconceptualization. Focus on Exceptional Children, 27(1), 1-16.

Gregory, E., \& Williams, A. (2000). City literacies: Learning to read across generations and cultures. New York: Routledge.

Guerra, J. C. (1998). Close to home: Oral and literate practices in a transnational Mexicano community. New York: Teachers College Press.

Heath, S. B. (1983). Ways with words: Language, life, and work in communities and classrooms. Cambridge, MA: Cambridge University Press.

Jiménez, R. T. (1997). The strategic reading abilities and potential of five low-literacy Latina/o readers in middle school. Reading Research Quarterly, 32(3), 224-243.

Jiménez, R. T. (2000). Literacy and the identity development of Latina/o students. American Educational Research Journal, 37(4), 971-1000.

Jiménez, R. T. \& Barrera, R. B. (2000). How will bilingual/ESL programs in literacy change in the next millennium? Reading Research Quarterly, 35, (4), 522-523.

Jiménez, R. T., García, G. E., \& Pearson, P. D. (1995). Three children, two languages, and strategic reading: Case studies in bilingual/monolingual reading. American Educational Research Journal, 32(1), 31-61. 
Jiménez, R. T., García, G. E., \& Pearson, P. D. (1996). The reading strategies of Latina/o students who are successful English readers: Opportunities and obstacles. Reading Research Quarterly, 31(1), 90-112.

Kalmar, T. M. (2001). Illegal alphabets and adult biliteracy. Mahwah, NJ: Erlbaum.

Lindholm-Leary, K. (2001). Dual language education. Buffalo, NY: Multilingual Matters.

Lucas, T., Henze, R., \& Donato, R. (1990). Promoting the success of Latino language-minority students: An exploratory study of six high schools. Harvard Educational Review, 60(3), 315-340.

Luke, A. (1995-1996). Text and discourse in education: An introduction to critical discourse analysis. In M. Apple (Ed.), Review of research in education (pp. 3-48). Washington DC: American Educational Research Association.

Macedo, D. (2000). The colonialism of the English only movement. Educational Researcher, 29(3), 15-24.

Moll, L. C. (1988). Some key issues in teaching Latino students. Language Arts, 65(5), 465-472.

National Center for Education Statistics. (1997). Are limited English proficient (LEP) students being taught by teachers with LEP training? Washington, DC: U.S. Department of Education.

National Center for Education Statistics. (1998a). Mini-digest of education statistics 1997. Washington, DC: U.S. Department of Education.

National Center for Education Statistics. (1998b). National assessment of educational progress (NAEP), 1992, 1994, 1998 reading assessments. Washington, DC: U.S. Department of Education.

National Center for Education Statistics. (1998c). Report in brief. NAEP 1996 trends in academic progress. Washington, DC: U.S. Department of Education.

New London Group. (1996). A pedagogy of multiliteracies: Designing social futures. Harvard Educational Review, 66(1), 60-92.

Nieto, S. (1992). Affirming diversity. New York: Longman.

Pace, D. (2001). Rapidly growing Hispanic population is slow to vote. News-Gazette, p. B-5.
Reyes, M. de la luz. (1992). Challenging venerable assumptions: Literacy instruction for linguistically different students. Harvard Educational Review, 62(4), 427-446.

Reyes, M., \& Halcón, J. J. (1997). Racism in academia: The old wolf revisited. In A. Darder, R. D. Torres, \& H. Gutiérrez (Eds.), Latinos and Education (pp. 423-438). New York: Routledge.

Sánchez, G. I. (1940). Forgotten people: A study of New Mexicans. Albuquerque, NM: University of New Mexico.

San Miguel, G. (1987). "Let all of them take heed": Mexican Americans and the campaign for educational equality in Texas, 1910-1981. Austin: University of Texas Press.

Soto, L. D. (1997). Language, culture, and power. Albany: State University of New York.

Steinberg, J. (2000). Bilingual ban yields higher test scores. Seattle Times, pp. 1,21 .

Sulzby, E., \& Teale, W. (1991). Emergent literacy. In R. Barr, M. L. Kamil, P. Mosenthal, \& P. D. Pearson (Eds.), Handbook of reading research, Vol. 2 (pp. 727-758). New York: Longman.

Thomas, W. P., \& Collier, V. (1996). Language-minority student achievement and program effectiveness. NABE News, 19(6), 33-35.

Thomas, W., \& Collier, V. (1997). School effectiveness for language minority students. Washington, DC: National Clearinghouse for Bilingual Education.

Tikunoff, W. J. (1985). Applying significant bilingual instructional features in the classroom. Rosslyn, VA: National Clearinghouse for Bilingual Education.

Valencia, R. R. (1991). Chicano school failure and success: Research and policy agendas for the 1990s. New York: Falmer Press.

Wells, G. C. (1986). The meaning makers: Children learning language and using language to learn. Portsmouth, NH: Heinemann.

Willig, A. C. (1985). A meta-analysis of selected studies on the effectiveness of bilingual education. Review of Educational Research, 55(3), 269-317. 


\section{Effective Curriculum for Students With Emotional and Behavioral Disorders}

Beverley Johns, E. Paula Crowley, Eleanor Guetzloe

This book is designed to show how to create specialized instruction based on the individualized needs of students with emotional and behavioral disorders. The book demonstrates throughout how to plan a curriculum based on a diagnostic prescriptive approach.

The authors stress that teachers must know as much as possible about each student. This includes strengths, deficits, interests, and behavioral functions. Teachers can then plan an appropriate program based on effective, direct instructional approaches.

\section{Special Features}

- Shows both social and academic interventions.

- Includes ideas for becoming partners with community agencies.

- Gives techniques for planning communication with parents.

- Helps teachers to plan engaged time in learning activities.

\section{Contents}

1. The Teacher as a Catalyst for Change

2. Assumptions Underlying Quality Educational Programming

3. Life Skills and Transition to Adulthood

4. Role of the IEP in Education of Students With E/BD

5. Meaningful and Relevant Curriculum

6. The Central Role of Teaching Social Skills

7. Multicultural Education for Students With E/BD

8. Curriculum of Hope: Focusing on Helping Others

9. Engaged Time in the Classroom

10. Student Self-Management

11. Higher-Level Thinking Skills

12. Learning Strategies and Study Skills

13. Access to the General Curriculum

14. Effective Inclusion of Students With E/BD

15. Working With Families of Students With E/BD

ISBN 0-89108-287-5 / 2002 / paperback / 256 pages 


\section{Professional update}

\section{Council for Exceptional Children}

April 3-6, 2002

New York, New York

Contact: www.cec.sped.org 800-486-5773

\section{American Educational Research Association}

April 1-5, 2002

New Orleans, Louisiana

Contact: www.aera.net

202-223-9485
Learning Disabilities Association of America

February 26-March 1, 2003

Chicago, Illinois

Contact: 40th Annual LDA International Conference 4156 Library Road

Pittsburgh, PA 15234

\section{American Association on Mental Retardation}

May 28-June 1, 2002

Orlando, Florida

Contact: www.AAMR.org 800-424-3688 